Article

\title{
The Book of Revelation: Hope in Dark Times
}

\author{
Francis J. Moloney
}

Department of Biblical Studies, Catholic Theological College, University of Divinity, Melbourne 3002, Australia; fmoloney@salesians.org.au

Received: 20 March 2019; Accepted: 27 March 2019; Published: 31 March 2019

check for updates

\begin{abstract}
Contemporary analysis of the world that produced the Book of Revelation suggests that Patmos was not a penal settlement, and there is little evidence that Domitian systematically persecuted Christians. The Emperor Cult was widely practiced, but Christians were not being persecuted for lack of participation. The document makes much of God's victory in the death and resurrection of Jesus Christ, the slain and standing Lamb (Rev 5:6). The "saints" were not persecuted Asian Christians but, under the influence of the Book of Daniel, John's presentation of those from Israel's sacred history who lived by the Word of God and accepted the messianic witness of the prophets $(8: 3-4 ; 11: 18 ; 13: 7$, $10 ; 14: 12 ; 16: 6 ; 17: 6 ; 18: 20,24 ; 19: 8 ; 20: 6,9)$. They already have life, the application of the saving effects of the slain and risen lamb "from the foundation of the world" (13:8). John addresses late first-century Asian Christians, presenting the model of these "saints," offering them hope as they are tempted by the allure of the Greco-Roman world and its mores. He invites them into the life and light of the New Jerusalem, the Christian church (22:1-5).
\end{abstract}

Keywords: hope; apocalyptic; eschatology; prophecy; martyrdom; death and resurrection; Book of Daniel; Jesus Christ; Greco-Roman society; Christian community

\section{Introduction}

The Book of Revelation is no doubt the most challenging book in the New Testament. Most mainstream Christians do not read it, but many Christians have used the fierce and often threatening imagery as biblical judgment against individual people and institutions across the ages. This practice was passionately and widely used across all sides of the tragic and often violent divisions that shook the Christian church and European society in general in the sixteenth century. ${ }^{1}$ It continues to guide many in their search to envision what will happen at the end of all time. Unfortunately, some fanatical groups (spectacularly, the mass suicides of members of the People's Temple at Jonesville in North Guyana in 1978, and the Siege of the Branch Davidian settlement at Waco, Texas, in 1993) have done great damage to themselves and to an understanding of Christianity through an incorrect reading of the Book of Revelation. It is not a book for religious fanatics, but over the centuries such Christians have kept it "in the news." It may seem odd to suggest that the message of this ambiguous and at times violent book may offer "hope in dark times."

Despite its challenging nature, the Christian Churches, especially in Western society, use the Book of Revelation in their liturgies. This is not so much the case in the East, where a long suspicion of its helpfulness as a "Word of God" has existed. ${ }^{2}$ In the Roman Catholic tradition the so-called Office of

1 The art of Lucas Cranach the Elder (1472-1553) and Albrecht Dürer (1474-1528) are eloquent testimonies of that era. However, they were not alone in graphically casting opposing Christian communities as the Antichrist, an expression that never appears in the Book of Revelation. See Eire (2016, pp. 178-84).

2 See Koester (2014, pp. 33-35). Koester shows the mixed reception the document received in the East down to 350 CE, and concludes: "Ambivalence about Revelation would continue in the eastern churches" (p. 35). 
Readings, part of its official Prayer of the Church, reads Revelation, in its entirety, from the Second to the Fifth Week of the Easter Season. At other places in the Church's liturgy, it appears regularly, especially as canticles and short readings in the Prayer of the Church (Paul 1974), in the weekly readings, or at the Sunday celebration of the Eucharist. ${ }^{3}$

From very early times, interpreters understood Revelation as the work of an author named "John," writing to fellow Christians from the island of Patmos, just off the coast of modern-day Western Turkey. On the basis of his words in Revelation 1:9, "I, John, your brother who share with you in Jesus the persecution and the kingdom and the patient endurance, was on the island called Patmos because of the word of God and the testimony of Jesus." ${ }^{4}$ John is understood to be suffering some form of isolation and imprisonment at the hands of Roman authorities for his witness to Christian faith.

Most contemporary commentators regard the text as directed to Asian Christians, identified in the seven letters found in 2:1-3:22, who are suffering persecution and martyrdom. The use of powerful images, clothed in highly symbolic and sometimes unimaginable language, tells of the mysterious but inevitable violent intervention of God at the end of time, conquering all evil powers. The classification of the Book of Revelation as a Christian apocalypse determines this dominant interpretation. It exhorts Asian Christians to resist the many evils associated with the Roman imperial system, even in the face of persecution and death. In the end, Rome will be destroyed and God will reign supreme. ${ }^{5}$

Late in the first and into the second Christian century, Jews and Christians developed an abundant form of literature classified as "apocalyptic." Such literature had already appeared in the Old Testament, especially in the Book of Daniel that appeared in mid-160 CE, during a time of severe persecution in Israel under the Seleucids, ruled by Antiochus IV from 175-164 BCE. In general terms, apocalyptic literature addresses communities that are facing difficulties that no human endeavor can reverse. Apocalypses are at one-and-the-same time earthly, because they address a human situation, and other-worldly, because divine intervention into human suffering resolves the crisis. In the end, God will punish and destroy the wicked, while the persevering faithful and those slain for the faith will be victorious. I have accentuated in the end because this is an essential element of apocalyptic literature. In more technical terms, the conflict between the good and the wicked is resolved by God's eschatological intervention, a decisive "end of human history" event. ${ }^{6}$

The Book of Revelation certainly uses an apocalyptic literary form, but this form has been adapted by a Christian author who is convinced that Jesus, the slain Lamb (see $5: 6 ; 13: 8)$, has been raised. As the author, a man named "John" (see 1:1, 4, 9; 22:8), opens his book, he exclaims: "To him who loves us and freed us from our sins by his blood, and made us to be a kingdom, priests serving his God and Father, to him be glory and dominion forever" (1:5b-6. See also 5:10). This is hardly the voice of a suffering figure asking his audience to persevere until God makes a final intervention to destroy the destroyers (see 11:18). On the contrary, he believes that Christians are already members of a royal priesthood because of the death and resurrection of Jesus. It is hardly Christian to ask believers to wait, and perhaps suffer, across a period that will lead to God's final intervention. What follows will suggest that the Book of Revelation, despite the literary form that it borrows from Jewish and Christian apocalyptic literature, is a Christian book, not a traditional apocalypse, but rather an extraordinary instruction on "hope in dark times."

3 The heavy concentration upon texts from Revelation during the Easter Season, and on Sundays (that recall the Easter event) raises the question of the relevance of the dictum lex orandi lex credendi for the interpretation of the book. See Moloney (2020b).

4 Citations of the Biblical text come from the NRSV translation. Occasionally I will use my own translation, indicated by the abbreviation AT (author's translation).

5 Although they differ in detail, influential representatives of this widely held apocalyptic interpretative paradigm are: (Collins 1979; Boring 1989; Aune 1997; Beale 1999; Giesen 1997; Prigent 2001; Boxall 2006; Lupieri 2009; Resseguie 2009; Koester 2014).

6 These few sentences do not do justice to the complexity of the history and the nature of the Jewish apocalyptic movement and its literature. Among many, see the authoritative work of Collins (2015). His definition of an "apocalypse" is widely accepted: "A genre of revelatory literature within a narrative framework, in which a revelation is mediated by an otherworldly being to a human recipient, disclosing a transcendent reality with is both temporal, in so far as it envisions eschatological salvation, and spiritual, insofar as it involved another, supernatural world" (pp. 4-5). 


\section{Date and Author}

Even though we correctly read and interpret Revelation as a unified literary piece, its final form probably resulted from a long literary journey marked by years of epistolary communication, missionary preaching, prophetic utterance and, even liturgical experiences. There appear to be hints of the first documented persecution of Christians by Emperor Nero (64 CE), who ruled from 54-68 CE, and allusions to the late first-century widespread sentiment that Nero was not dead but would return from the East (Parthia) to overthrow current Roman authority. This so-called Nero-redivivus expectation is generally (but not only) associated with such passages as the description of the beast rising out of the earth in 13:12: "It exercises all authority of the beast in its presence, and makes all the inhabitants of the earth worship the first beast, whose mortal wound was healed," and the interpretation of the number 666 in 13:18 as "Nero."

Since late in the second Christian century, especially under the influence of Irenaeus' Against Heresies 5.30.3 (c. $180 \mathrm{CE}$ ), the Book of Revelation has been associated with the latter years of the Emperor Domitian (Emperor: 81-96 CE). It is possible that traditions coming from across fifty years, from the 1960s until the end of the first century CE formed the Book of Revelation as we have it in our Bibles. Its final articulation, however, forms a carefully constructed literary, pastoral, and theological unit. ${ }^{8}$ Justin Martyr (100-165 CE. See his Dialogue with Trypho 81.4) already regarded the book as part of early Christian literature. From the time of Irenaeus, the author has been identified with the Apostle, John the son of Zebedee, although some claimed that this could not be the case, given the obscurity and complexity of the book (Gaius: early third century CE; Dionysius of Alexandria: latter half of the third century). It differed too radically from the Johannine Gospel and Letters. The first Christian church historian, Eusebius, who reports the views of Gaius and Dionysius, also indicated his doubts about traditional Johannine authorship in his Historia ecclesiastica $(3.28 ; 7.25)$ early in the fourth century CE (c. 322-326 CE).

Nowadays, most would claim that it is not possible for us to identify the person and the role of the author with any precision. The author names himself "John," and this claim should be accepted. It was a widely-used name, but there are no clear indications who this "John" might be. We simply do not have enough information from the world that produced Revelation, or from the document itself, to make a firm decision about the precise identity of the "John" of Revelation. David Aune, one of the most significant commentators on the Book of Revelation, satisfactorily identifies the author as follows:

While the final author-editor of Revelation was named "John," it is not possible to identify him with any other early Christian figures of the same name, including John the son of Zebedee or the shadowy figure of John the Elder. The otherwise unknown author of Revelation in its final form was probably a Palestinian Jew who had emigrated to the Roman province of Asia. ... He regarded himself as a Christian prophet. ${ }^{9}$

The Jewishness of John is strikingly evident in his extraordinary use of the Sacred Scriptures of Israel, and his familiarity with Jewish apocalyptic literary forms. The text of the Book of Revelation is full of repeated allusions to the Scriptures, especially the Torah, Isaiah, Ezekiel, and Daniel. However, unlike other early Christian authors, John never cites his biblical sources. His literary world is entirely Jewish. ${ }^{10}$

7 Giving numerical value to the letters of the Greek "Nerōn Caesar" produces 666. See especially Bauckham (1993a, pp. 384-407).

8 Earlier scholarship questioned this. See especially Charles (1920). The case for literary unity has been strongly argued by Thompson, Revelation, pp. 37-42, and is nowadays generally taken for granted (see Corsini, Boring, Bauckham [Climax, x], Boxall, Koester). However, Aune, Revelation, 1: cxviii-cxxxiv, has recently argued for identifiable "editions" in the canonical text.

9 Aune, Revelation, 1:lvi. I have modified Aune's description by eliminating his identification of the author as a Jew fleeing during the first Jewish revolt in 66-70 CE. This cannot be proven.

10 On John's use of Israel's Sacred Scriptures, see Beale, Revelation, pp. 76-99, and Moyise (1995). Although they disagree on John's use of them, Beale and Moyise argue convincingly for Israel's Scriptures as the determining source for the Book of Revelation. 


\section{Genre}

The use of the letters to the seven churches (2:1-3:22) links Revelation to the genre of a letter, although those "letters" do not follow the traditional form of an early Christian letter. No doubt the document was written by a Christian to be communicated to fellow Christians, and the use of letter features indicates that such was the case. However, its major literary characteristics are apocalyptic and prophecy. The problem with labelling Revelation as a Christian version of traditional Jewish "apocalyptic" literature is that this label determines the interpretation. To use a well-worn image: the tail wags the dog. This approach does not do justice to the fact that the victory of the Lamb is portrayed as already won across the narrative.

\subsection{A Christian Apocalypse?}

The bulk of the message of the book of Revelation is communicated through the language and imagery found in Jewish and Christian apocalyptic literature. Most interpreters suggest that Revelation is a unique example of late first-century Christian apocalyptic literature. However, is that clearly the case?

After the epistolary salutation of 1:1-3, Jesus Christ is presented in the prologue to the document as part of a heavenly trinity, the first born from among the dead, and the ruler of kings on earth (vv. 4-5). The audience participates in the letters to the seven churches, which may have a deeper meaning than the seven letters of exhortation and warnings to seven churches in Asia, indicating the recipients of John's document (2:1-3:22). Behind the letters, the audience senses allusions to Israel's sacred history, from the primeval history of Genesis $(2: 4-5,7)$ to Christ, standing at the door, knocking (3:20). The promises made to the victors across the letters (see 2:7, 11, 17, 26-28; 3:5, 12, 21) may be an appeal to the audience to be a truly Christian people and church, "a kingdom of priests, serving his God and Father" (1:6. See also 5:10). ${ }^{11}$ The letters are followed by the vision of a solemn liturgy that takes place in heaven (4:1-5:15). The climax of that vision is the appearance of a Lamb, already victorious: slain yet standing (5:6). The heavenly court sings his praise, recognizing that his death has ransomed all humankind (5:9-14). Because of this, he is "worthy to take the scroll and open its seals" (v. 9). The Lamb receives universal praise and worship (vv. 11-14). The "narrative" has only just begun. However, John has proclaimed that the slain yet standing Lamb is already victorious.

This victory is narrated before the sevens of the seals, the trumpets, and the bowls, and is told again as each seven comes to closure. It is repeated in the silence that greets the opening of the seventh Seal (8:1) marking the end of the period from creation to Jesus' death and resurrection (see 7:1-8), and the establishment of period of universal salvation enabled by that death and resurrection (7:9-17). It is promised in the blowing of the sixth trumpet that "in the days when the seventh angel is to blow his trumpet, the mystery of God will be fulfilled" (10:7). Consequently, the blowing of the seventh trumpet results in the opening of God's temple, as "the kingdom of the world has become the kingdom of the Lord and his Christ" (11:15-19).

After a threefold preparation, addressing the ambiguity of the human condition (12:1-18), describing the action of Satan's agents in spreading evil (13:1-18), and God's initial intervention on behalf of the saints of Israel (14:1-20), the seven bowls are poured out in 15:1-16:21. Again prefaced by a heavenly encounter (15:1-8), the lines are drawn for battle (16:1-21). The battle of Harmagedon tells of the definitive conflict between good and evil at the cross of Jesus Christ. ${ }^{12}$ The victory is once more announced: "It is done" (16:17). The threefold consequences of this definitive victory are then spelt out in detail. Babylon is destroyed (17:1-19:10); all evil power is definitively eliminated by God's victory in

11 Many of the promises to the victors in the letters of 2:1-3:22 return in the description and the role of the New Jerusalem in 21:9-22:5. See Corsini, Apocalisse, pp. 383-86; Boxall, Revelation, p. 312; Resseguie, Narrative Commentary, p. 258; (Vanni 1991).

12 The transliteration of harmagedōn as "Harmagedon" respects the NRSV. In English commentary and in popular reference to an end-time battle, however, it is frequently rendered as "Armegaddon". 
the death and resurrection of Jesus (19:11-20:15), and the chosen ones are gathered into the messianic kingdom that may not be "other-worldly," but a God-given Christian community (21:9-22:5).

John's audience is not given a road map to God's otherworldly eschatological victory; but it is roundly and repeatedly instructed that life and light have been made available in the New Jerusalem, the Christian community as it should be (see 22:1-5). Revelation does not hold its audience in anxious tension, dominated by exhortation to "endure" persecution and suffering, or "resist" false claims to divinity, waiting for God's final saving intervention. These themes, especially the theme of "resistance," are certainly present, but they are not the key to its secrets. John repeatedly affirms that the victory has already been won by "the Lamb who was slain from the foundation of the world" (13:8 AT). ${ }^{13}$

Among others, Craig Koester has recognized this odd aspect of the document when read as a thoroughgoing example of an apocalyptic literary form. He points out, as I have, that "Revelation departs from the usual pattern" of apocalyptic literature. He states that "[ $t]$ he eschatological struggle had already begun with the Messiah's exaltation and would culminate at his return. Those events define the present time." 14 However, this does not explain John's repeated claim that the victory has already been won; indeed, "It is done" (16:17). For John, it has not "already begun" with the Messiah's exaltation. It is not "in process," but has been realized in the perennially available saving action of God in the death and resurrection of Jesus. It is available in the New Jerusalem, the Christian church.

No doubt the recipients of John's Book of Revelation faced difficulties. Many of these difficulties were created by the widespread influence of the Greco-Roman religious practices within the powerful and universal political presence of the Roman Empire. Some of them, if we are to judge by what is said to the seven churches (see 2:4, 14-16, 20-23; 3:1-3, 15-16), arise from the fragility of their own commitment. However, John's primary concern is not to exhort them to wait in faith and hope for God's final eschatological victory. The document is studded, from beginning to end, with proclamations of the victory of God from all time in and through the slain and risen Lamb (see 5:6, 9-14, 7:12-8:1; $11: 15-19 ; 16: 17-21 ; 18: 20-24 ; 19: 1-8,17-21 ; 20: 11-15 ; 21: 1-22: 5)$. There must be a tension, as in all Christian literature, between what God has already achieved in and through Jesus Christ and his final return. However, the decisive victory has been won. God's saving history, revealed throughout Israel's story and in the Christian church, rejoices in what God has done for humankind across history through the saving event of the death and resurrection of Jesus Christ, from before the foundation of the world. Although not a solitary voice in the New Testament (see Rom 16:25-26; Col 1:17-20; Eph 1:1-7; 2 Tim 1:9-10), John makes a singular contribution to emerging Christian thought by associating the saving power of Jesus Christ's death and resurrection with the entire course of human history (see 5:6;13:8). ${ }^{15}$

\subsection{A Christian Prophecy?}

The recipients of Revelation were certainly made aware of what God has already achieved. They are nevertheless exhorted to call out: “Come, Lord Jesus!" (22:20). The use of the category "realized eschatology" does not indicate that all expectations of God's final intervention in the return of Jesus Christ as judge have been eliminated from John's understanding of sacred history. The recipients of

13 This is the obvious translation of the Greek of 13:8: hou ou gegraptai to onoma autou en tōi bibliōi tēs zōes tou arniou tou esphagmenou apo katabolēs kosmou. The NRSV, however, translates: "and all the inhabitants of the earth will worship it, everyone whose name has not been written from the foundation of the world in the book of life of the lamb that was slaughtered." The translators could not accept that the Lamb was slaughtered from the foundation of the world. They place the better translation in a note to the text. Aune, Revelation, 2:747, agrees with the NRSV translators, commenting that "it is logically and theologically impossible to make sense of the statement that 'the Lamb was slaughtered before the foundation of the world'." Koester, Revelation, p. 575, agrees. Rejecting what is clearly stated by the Greek, they fail to see the unique theological contribution John makes to developing Christian thought, with its own logic, as they work with a linear time that John transcends.

14 (Koester 2014, p. 107).

15 The widespread Eastern Christian iconographic theme of the Anastasis portrays the risen Jesus' descensio ad inferos (descent into hell), leading Adam and Eve into life by taking their hands. The Old Testament kings and prophets look on. Although the artistic tradition is associated with the temporal, indicating what happened in the silence of Holy Saturday (see 8:1), it can also be interpreted as an indication of the transtemporal saving effects of Jesus' death and resurrection "from the foundation of the world" (13:8). 
Revelation are exhorted to live confidently in the glitter of a Greco-Roman world, aware of the saving effects of the death and resurrection of Jesus. However, they must still face the challenges of a world marked by the ambiguous presence of grace and sin: "Let the evildoer still do evil, and the filthy still be filthy, and the righteous still do right, and the holy still be holy" (22:11. See also vv. 14-15). ${ }^{17}$ Such ambiguity will be finally resolved only when the Lord Jesus comes (22:20).

John regards his work as prophecy $(1: 3 ; 19: 10 ; 22: 7,10,18,19)$. He has been given a commission to prophesy (10:11). A link with traditional biblical prophecy is certainly a feature of John's practice of interlacing his narrative with allusions to the biblical prophets, especially Isaiah, Ezekiel, and Daniel. The Hebrew Bible, and not the speculations of Jewish or Jewish-Christian apocalyptic literature, forms the essential literary backbone to Revelation, even though it is never directly cited. ${ }^{18}$ There was another understanding of the expression "prophet" in early Christianity, a prolongation of the spirit of traditional prophecy that makes a link with both the Hebrew Bible and the message of Jesus. Contemporary Gospel studies show that many of the so-called "words of Jesus" are in fact "words of early Christian prophets." As M. Eugene Boring puts it: "Christian prophets were thus those who spoke the message of the risen Lord directly to the Christian community."19 John's prophetic utterances address Christians at the end of the first century with the message of the saving effects of the death and resurrection of Jesus.

\subsection{Genre Bending}

In his 2001 presidential address to the Society of Biblical Literature, Harold W. Attridge suggested that the author of the Fourth Gospel regularly used traditional genres that lead an audience to expect usual outcomes. However, he "bends" them, thus taking an audience into unexpected and unexplored possibilities. ${ }^{20}$ He describes the practice as follows:

In many cases where it is possible to identify significant generic parallels, and therefore presume that the form in question generates regular expectations, the reader encounters something quite odd about the way in which the generic conventions seem to work. ${ }^{21}$

John's marriage of letter-prophetic-apocalyptic literary forms, with the dominant form being apocalyptic, "bends" expectations. The expectation is that an author's use of apocalyptic envisions an eschatological salvation. ${ }^{22}$ While the message of God's intervention in the descent of the heavenly Jerusalem remains in place, for John, the victory has already been won, and the gift of the heavenly Jerusalem refers to the earthly reality of the Christian church. The key to the genre bending in Revelation is the death and resurrection of Jesus of Nazareth, a consequence of the incarnation, an event that took place once and for all within a human story. For John, this event transformed human history from the beginning of time until the present age. It is the centre-point of God's perennial saving presence, giving meaning to the whole of human history. ${ }^{23}$

17 Although highlighted in the epilogue of Revelation (see 22:11, 14-15), the theme of the ongoing presence of evil and lack of repentance despite God's action in the death and resurrection of Jesus Christ, is regularly stated (see 2:1-3:22; 16:8-9, 10-11, $21 ; 18: 4 ; 21: 8,27 ; 22: 3)$.

18 See above, n. 10.

19 (Boring 1989, p. 25).

20 (Attridge 2002).

21 Attridge, "Genre Bending", p. 11.

22 See above, n. 6, for John J. Collins' widely accepted description of apocalyptic, where God's eschatological intervention is an essential part of the genre.

23 The remainder of this essay, starting from some contemporary questioning of traditional interpretation of the Book of Revelation, depends upon the author's study, The Apocalypse of John. An Alternative Commentary (Moloney 2020a). Documentation for discussions surrounding the case made below appears in that study. It is inspired by two works of (Corsini 1980, 1983); ([Repr. Eugene, OR: Wipf \& Stock, 2019]) and (Corsini 2002). 


\section{Further Questions}

There is no evidence that Patmos was a penal settlement for persecuted Christians. The only piece of evidence is Revelation 1:9. Perhaps John's self-introduction may be more about his preparedness to undergo trials because of his missionary and prophetic role: "because of the word of God and the witness to Jesus" (AT of dia ton logon tou theou kai tēn martyrion İesou) than his endurance as a persecuted Christian. As Craig Koester admits: "John is the only person known to be sent there." ${ }^{4}$ Too much has been constructed upon this "decidedly unimaginative" (Boxall) biographical interpretation of 1:9.

Despite Eusebius' claim that he was a violent persecutor of Christians (Historia ecclesiastica 3.17-20), there is little or no evidence that Christians suffered a systematic persecution under Domitian. ${ }^{25}$ This is widely acknowledged nowadays. Most have recourse to the suggestion that he imposed the Emperor cult on the Empire, and that Revelation is a response to his false claim to divine authority. Evidence for the practice of the Emperor cult in Asia is widespread; ${ }^{26}$ but evidence for the persecution of the Asian Christians for lack of observance of the cults is hard to find. Such practices certainly became prevalent later in the second Christian century, but drawing them back into the last decade of the first century is widely regarded as anachronistic. ${ }^{27}$ As Ramsey MacMullen puts it: "Had the church been wiped off the face of the earth at the end of the first century, its disappearance would have caused no dislocation in the empire, just as its presence was hardly noticed at the time. ... Simply, it did not count."28

Almost all interpreters read 1:10-11,19-20, and 2:1-3:22 as an indication that seven Asian churches were the recipients of this apocalyptic circular letter. For many, John wrote Revelation to address the trials and temptations of the seven churches, suffering under Domitian, tempted by or forced into the Emperor cult. Interpreters strain to identify people and problems explicitly mentioned in the letters (e.g., Nicolaitans, Antipas, Jezebel, Balaam, Balak, and the synagogue of Satan). It is equally difficult to identify why John credits certain strengths and failures to some communities, and not to others. As Koester remarks: "in almost every instance the images used for one city would fit the others just as well." ${ }^{29}$ The focus upon the named Asian churches and their failures in the face of Roman persecution and the imposition of the Emperor cult as the dominant motivation for the writing of Revelation is running out of support in contemporary scholarship.

Why did John choose these "seven" churches? There were other (more important?) cities in the region where Christian communities were located that are not mentioned (e.g., Colossae). Across the Book of Revelation, the number "seven" is an indication of completeness. Perhaps the "seven" churches are a symbol of the whole church, and not only the names of churches to which Revelation was sent. ${ }^{30}$ Interpreters regularly find parallels between the letters to the seven churches in 2:1-3:22 and the description of the New Jerusalem in 21:9-22:5. John challenges a fragile church, struggling in the midst of the allure of Greco-Roman society and its mores, as he opens his document (2:1-3:22). He closes it with a description of the church as God's gift (21:9-22:5). ${ }^{31}$

24 Koester, Revelation, p. 239. Despite this, Koester (pp. 239-43) accepts that he is in Patmos as the result of a lenient sentence from provincial authority. For a survey of the interpretation of Patmos since 1900, see (Boxall 2013, pp. 230-31). He regards the dominant interpretation of Patmos as a penal settlement as "decidedly unimaginative" (p. 5). On the missionary interpretation, see (Thompson 1990, pp. 172-73); Corsini, Apocalisse, p. 81.

25 Thompson, The Book of Revelation, pp. 107-115.

26 See Friesen (2001).

27 See Thompson, The Book of Revelation, pp. 104-107; Friesen, Imperial Cults, pp. 25-131; (Klauck 2003, pp. 250-330; Howard-Brook and Gwyther 1999, pp. 115-19; Brodd and Reed 2011), especially the essays (which generated and concluded the discussion) of the Roman historian, Karl Galinski, “The Cult of the Roman Emperor: Uniter or Divider?" (pp. 1-21), and "In the Shadow (or Not) of the Imperial Cult: A Cooperative Agenda" (pp. 215-25).

28 (MacMullen 1984, p. viii).

29 Koester, Revelation, p. 233. See also Beale, Revelation, p. 227: “[A]11 the letters deal generally with the issue of witnessing for Christ in the midst of pagan culture".

30 Among many, see Bauckham (1993b, pp. 114-17). The number "seven" does not indicate "perfection," but "completion."

31 See above, n. 11. 
As we have seen, the identification of the beast, whose name is 666 as Nero (13:18), necessarily identifies the corrupting presence of evil (see 13:1-18) with the Roman Empire. The association of the prostituted woman with the "seven mountains on which the woman is seated" (17:9) is widely accepted as an endorsement of this identification. Although aware of the symbolic importance of the number "seven" in Revelation, almost all interpreters regard this as an allusion to Rome. In the first place, 17:1-14 relies heavily on the use of "seven" to indicate "completeness" (see 17:1 [twice], 7, 9 [twice], 11). The woman is intimately associated with universal and ongoing corrupt use of power. Rome certainly is part of that, and is the current problem. However, the seven mountains represent the presence of corrupt power across Israel's history, from Babylon to Rome. Interestingly, Rome has always been associated with seven "hills" (Greek: lophos), never with "mountains" (Greek: oros, as in 17:9). Werner Foerster objects to the association of oros with Rome: "that the hills are the hills of Rome does not fit too well." He associates himself with the importance of the use of "seven" as he suggests that they indicate "a power that spans the centuries." 32

"Babylon the Great" (18:2) is traditionally identified with Rome. A case can be made for the identification of "Babylon the Great" with the now destroyed former Jerusalem, unfaithful Israel, "drunk with the blood of the saints and the blood of the witnesses to Jesus" (17:6). Perhaps these "saints" are not Christian martyrs, but are the holy ones of Israel. The New Jerusalem, understood by John as the Christian church, replaces the former Jerusalem, too easily corrupted and "drunk with the blood of the saints."

If Patmos is not a penal colony, John was not there enduring a suffering imposed by Roman authority. If there was no systematic persecution under Domitian, or widespread imposition of the Emperor cult in the Asian churches at the end of the first century, a critical question emerges. Who are those who have suffered and even died because of their adherence to the Word of God and their testimony to Jesus in $1: 2,9 ; 6: 9 ; 12: 17 ; 18: 24 ; 19: 10 ; 20: 4$ ?

\section{Who Are the Saints?}

Those who have suffered and even died at the hands of Satan and his beastly agents are regularly called "the saints" $(8: 3-4 ; 11: 18 ; 13: 7,10 ; 14: 12 ; 16: 6 ; 17: 6 ; 18: 20,24 ; 19: 8 ; 20: 6,9)$. Who are they? Most interpreters take it for granted that they are Christian martyrs. In the light of the questions asked above, this claim should be queried. It is more likely that John looks back to the recent past, during the persecution of Antiochus IV, to the Saints of the Most High, those holy ones in Israel who were loyal to the commandments of God, and placed their hopes in the messianic promises of the prophets (see Dan 7:21, 25, 27; 9:5-6a, 10). John's biblical allusions draw from across many pages of the Hebrew Scriptures, especially (but not only) the Torah, Isaiah, Ezekiel, and Daniel. His regular references to those who suffer and are slain for the word of God and the messianic promises of the prophets (see $1: 2,9 ; 6: 9 ; 12: 17 ; 18: 24 ; 19: 10 ; 20: 4)$ look back to the era before the historical events of the death and resurrection of Jesus Christ. The experiences and vindication of the suffering and slain "saints" come to him from Israel's recent experience of persecution under Antiochus IV of Syria, and the writing that emerged from that experience: the Book of Daniel.

The literary character of the prophet Daniel played admirably into John's argument. On the one hand, the literary fiction created by Daniel set the tales across the four empires of the Babylonians (Dan 1-5), the Medes (6:1), the Persians (10:1), and the Greeks (10:20). The earlier chapters (Dan 1-6) do not necessarily refer to the period of Antiochus IV. They convey a message of persecution of Jewish saints across the entirety of its history under political and religious tyranny. Across Daniel 7-12, allusions to the period of Antiochus IV and the Maccabean revolt are clear. The book appeared in its current state between 167-164 BCE. By the time John wrote the Apocalypse, Daniel was exercising considerable influence in Jewish literature. Even in the pre-Christian period, in both the early Greek

32 (Foerster 1968). In 1 Enoch 24:3-4, Jerusalem is described as "seven mountains." 
translations and Qumran, Jewish interpreters recognized that Daniel addressed the period of Antiochus IV. The Jewish historian Josephus regarded Daniel as "one of the greatest prophets" (Jewish Antiquities $10.10-11 \S 266) .^{33}$

Sharply aware of the recent persecution and executions under Antiochus IV, John can address his audience by looking back to the prophet Daniel, claiming that the "saints" of Israel already participated in the life-giving fruits of the death and resurrection of Jesus. Daniel indicates why this happened: they observed the commandments and listened to the prophets (see Dan 9:5-6, 10. See also Bar 1:14-2:5; 3:1-8). As Steve Moyise puts it: "Whether they were facing actual persecution or not, it seems clear that John wishes them to see their situation in the light of the life and death struggle of Daniel and his friends." ${ }^{34}$ We cannot be sure; however, John's continual recourse to Daniel may well have been the reason for the choice of the apocalyptic genre for his document however much he has "bent" the genre because of his focus upon the death and resurrection of Jesus.

For John, Israel's "saints" (see especially Dan 7:15-27) anticipated eternal redemption provided by the blood of the crucified and risen Lamb, slain before the foundation of the world (Rev 5:6;13:8). At the heart of John's message lies the perennial presence of the reality of Jesus' death and resurrection, and its saving effects. Corrupt political and religious tyranny led to the life-giving participation of the saints across the whole of Israel's regularly corrupted religious and political history, from Babylon to Rome. The presence of the satanic did not begin or end with Rome; however, much the Roman Empire and the Imperial Cult may have impacted on John's audience. The history of corruption, rejection of God, and persecution has marked the whole span of Israel's sacred history, and it has always been marked by the presence of its "saints."

\section{A Proposed Literary Design}

The following literary design of Revelation 1:1-22:21, read as a single utterance, no doubt the result of a long literary history, depends upon three criteria. One of them is theological and the other two are literary.

1. The central message of the Book of Revelation is that the death and resurrection of Jesus reveal the meaning of the history of God's intervention into the affairs of humankind, recorded in the period of Israel and the period of the Christian community, a sacred history that runs from the foundation of the world to the time of the church.

2. This message is repeated multiple times, making known (i.e., revelation: apokalypsis), the full meaning of the perennial presence of God's saving action in and through Jesus Christ.

3. The "sevens" determine the literary shape of the whole utterance. Each "seven" is introduced by a description of heavenly encounters $(1: 9-20 ; 4: 1-5: 14 ; 8: 2-6 ; 15: 1-8)$. The pouring out of the seven bowls, the climactic announcement of Jesus' victory through death and resurrection, receives the most extensive treatment (12:1-22:5).

There are surprises at every turn. Even though John is moved to communicate with his audience within the political, religious and social presence of the Roman Empire, he does not limit his criticism to Rome. Inspired by Daniel's critique of all who have brought corruption and evil into Israel's history, from Babylon to Rome, his concern is to indicate that the death and resurrection of Jesus is a victory over all evil powers, and all false gods. For example, the books of Genesis and Exodus provide the background for the account of the woman and the dragon in 12:1-18. Daniel is used to develop a critique of the beast that reaches beyond an attack on Roman authority and its vassals to all corrupting authorities and their agents in 13:1-18.

33 For surveys of the reception of Daniel, see Casey (1979, pp. 51-141; Goldingay 1989, pp. xxvi-xxxviii; Collins 1993, pp. 72-89).

34 Moyise, The Old Testament, p. 58. 
The figure of the woman (hē gunē) looms large. Despite her glorious first appearance (12:1), by the time the passage closes in vv. 17-18, she and her descendants are in an ambiguous situation, pursued by Satan, but protected by God. In 17:1-6, mounted on the beast, her ambiguity has disappeared. The woman has made her decision to enter an unholy union with evil. However, that is not the end of her story. She returns at its end as the bride of the Lamb in 21:1-22:5. Such readings are possible because the battle of Armegeddon in 16:1-21 can be understood as the crucifixion of Jesus, fulfilling what was promised in 10:7: "In the days when the seventh angel is to blow his trumpet, the mystery of God will be fulfilled, as he announced to his servants the prophets." In the crucifixion of Jesus, the pouring out of the seventh bowl, "it is done" (16:17), is a definitive victory over evil that has already been described in the opening of the seventh seal $(8: 1)$ and the blowing of the seventh trumpet (11:15-19).

Revelation is to be read as a steady statement and the restatement of the saving effects of the death and resurrection of Jesus Christ, acting from before all time (5:6; 13:8), a call to live through challenge, conflict, suffering, and failure, in the light of the victory of the Lamb. The earliest extant Latin interpreter of the Book of Revelation, Victorinus of Pettau (c. 250-303), argued that the opening vision of the slain and standing Lamb as the only one with authority to open the seals of the scroll indicates that the meaning of the whole of Scripture is revealed through Christ's death and resurrection (Commentary on the Apocalypse, $1.4 ; 4.1-5.3){ }^{35}$ As far as the internal order of the document is concerned, he suggests:

We ought not pay too much attention to the order of what is said. For the sevenfold Holy Spirit, when he has passed in review the events to the last time, to the very end, returns again to the same times and supplements what he had said incompletely (Commentary on the Apocalypse 8.2.). ${ }^{36}$

By means of ever-deepening statement and restatement, the book is a celebration of the significance of the death and resurrection of Jesus, the mystery of God perennially present across the whole of sacred history, from the beginning of creation down to the time of the Christian church.

\section{I-1:1-8: Prologue}

\section{II-1:9-3:22: The Seven Churches:}

1:9-20: Part One: A two-staged encounter between John and the heavenly

2:1-3:22: Part Two: The Seven churches: retelling Israel's story leading to the coming of the Son of Man, Messiah. The letters recapture Israel's sacred history to address the dangers of mediocrity in the Asian churches

\section{III-4:1-8:1: The Seven Seals}

4:1-5:14: Part One: A heavenly liturgy prepares for the opening of the seals 6:1-8:1: Part Two: Opening the seals:

6:1-8: The opening of the first four seals: the human situation with steady allusions to Genesis

6:9-8:1: The opening of the final three seals: the divine response to the human situation

\section{IV-8:2-11:19: The Seven Trumpets}

8:2-6: Part One: A heavenly liturgy prepares for the blowing of the trumpets

35 For the texts, see Weinrich (2011, pp. 2, 6-10).

36 Weinrich, Ancient Christian Texts, p. 12. Koester, Revelation, p. 33, explains: "People were not to look for a sequential outline of future events in revelation but were to ask about its underlying meaning.... Revelation recapitulates the same meaning many times." 
8:7-11:19: Part Two: Blowing of the trumpets:

8:7-13: The blowing of the first four trumpets with steady allusions to Exodus

9:1-11:19: The blowing of the final three trumpets and the woes upon humankind

\section{V-12:1-22:5: The Seven Bowls}

12:1-14:20: The threefold preparation for the pouring out of the bowls:

12:1-17: Part One: The woman and the ancient serpent, the Devil and Satan

13:1-18: Part Two: The two beasts: collusion of corrupt religious and political authority

14:1-20: Part Three: The salvation of the faithful in Israel, an anticipated effect of the blood of the Lamb

15:1-16:21: The pouring out of the seven bowls:

15:1-18: A heavenly liturgy prepares for the opening of the seals

16:1-9: Pouring out of the first four bowls (allusions to the plagues in Egypt)

16:10-21: Pouring out of the last three bowls: leading to the Lamb's saving action

17:1-22:5: The threefold consequences of the death of Christ:

17:1-19:10: First consequence: the destruction of Babylon (Jerusalem)

19:11-20:15: Second consequence: the destruction of all evil power

21:9-22:5: Third consequence: the gathering of the chosen

\section{VI-22:6-21: The Epilogue}

22:6-9: The words of the interpretation of this book: the angel, the prophet, Jesus, and the call to worship God

22:10-17: The words of the interpretation of this book: the angel, the prophet, Jesus, and the call to "come"

22:18-21: The words of the interpretation of this book: warning, promise, and response

\section{Consequences}

The use of "sevens" determines the narrative: the seven churches (1:9-3:22), the seven seals (4:1-8:1), the seven trumpets (8:2-11:19), and the seven bowls (12:1-22:5). They are framed by a prologue $(1: 1-8)$ and an epilogue (22:6-21). In order to place the churches, the seals, the trumpets, and the bowls at the centre of the book's argument, John uses other literary indicators. All four "sevens" have a "preparation" for their administration. A heavenly revelatory experience introduces the Letters (1:9-20), heavenly liturgies introduce the seals (4:1-5:14), the trumpets (8:2-6), and the bowls (15:1-8).

Given the climactic importance of the seven bowls (15:1-16:21), concluding and clarifying much of what has been said more enigmatically in the letters, the seals, and the trumpets, greater attention is given to the development of this section, linked by the appearance of three "signs" (sèmeia) in heaven (See 12:1, 3; 15:1). John provides the description of the pouring out of the bowls (15:1-16:21) with a three-part preparation, describing the ambiguity and the promise inherent in God's initial intervention (12:1-14:20). He follows the pouring out with a threefold description of the consequences of the pouring out of the bowls, indicating the destruction of all evil forces, and the conclusion and perfection of God's initial intervention in the death and resurrection of Jesus Christ. This event opens a new era 
marked by the presence of the Christian community (17:1-22:5). ${ }^{37}$ Ambiguity remains, but God has conquered evil (17:1-20:15) and the grace of the Lord Jesus is available in the church (21:1-22:5).

John is not writing into a situation experiencing systematic persecution or being forced into Emperor worship. John's Christians are not told to "keep the faith," with the promise that, in the end, God will come in power and might to destroy the persecutors. Revelation is nonetheless directed to Christians facing a situation of great ambiguity, caught between belief in the saving effects of the death and resurrection of Jesus, and a subsequent lifestyle that belief requires, and the allure of the glittering Greco-Roman world within which they lived. In that respect, a "theology of resistance" is part of John's message but subordinated to the proclamation of the perennial saving presence of God in the death and resurrection of Jesus. In the meantime, "outside are the dogs and sorcerers and fornicators and murderers and idolaters, and everyone who loves and practices falsehood" (22:15) and "the righteous still do right, and the holy still be holy" (v. 11).

John exhorts Christians living in the Greco-Roman world of the late first century to shun the immoral and commercial glitter of that world, aware that they already enjoy the life given by God in and through the death and resurrection of his Son. John was neither a starry-eyed apocalyptic thinker, nor someone who thought that Christians already lived the glories of the risen life (see 1 Cor 15:20-58). Like all other early Christian writers, he faced the ambiguous reality of Christians called to live their lives in imitation of the crucified and risen one within a socio-political-religious context that radically opposed such a lifestyle.

All post-Christ believers live the in-between-time, negotiating its ambiguity. John exhorts his audience to look back upon the "endurance" of the saints in the face of devastating evil that was part of Israel's sacred history, the result of the fall of humankind and the fall of Satan (see 14:12). Demonic disasters challenged humankind, and creation itself, as a result of those "falls." However, from the foundation of the world, redemption by the blood of the slaughtered lamb was available $(5: 6 ; 13: 8)$. Those who observed the Law, and listened to the messianic prophecies, already in the period prior to the historical event of Jesus Christ, had been swept into that redemption. They share in the "first resurrection." "Over these the second death has no power, but they will be priests of God and Christ and they will reign with him a thousand years." 38 John encourages his early Christians to shun the false promises of the demonic world that still surround them as they await God's final appearance. The world of false promises and its agents have not disappeared because of the death and resurrection of Jesus as the ambiguity of Christian history itself indicates so eloquently. ${ }^{39}$

Living the in-between-time, Christians cry out "Come, Lord Jesus!" (22:20). John wrote his book to instruct them that they had every reason for hope, courage, and confidence as they lived their Christian lives in the expectation of a final coming. John attempts to focus a Christian community, aware of the allusive possibilities of apocalyptic language, upon the vividly remembered treasure of the holy ones of Israel, especially as the Book of Daniel represents "the holy ones." "Christians lived quiet lives, not much different from other provincials. The economy, as always, had its ups and downs;

37 The interpretation offered here indicates my response to the question I raised in $\mathrm{n}$. 3. The traditional dictum lex orandi lex credendi applies. The Christian church's consistent use of Revelation at Easter time, and in celebrations that recall Easter, points to its being a book that should be understood in the light of the death and resurrection of Jesus, not a prophecy about the end of time. See Moloney (2020b), Reading Revelation.

38 This interpretation of the "thousand years reign" as the period of Israel, prior to the unleashing of Satan for the final battle of Jesus' death and resurrection, challenges almost all interpretations of Rev 20:1-6. The thousand years do not indicate a precise chronological period that will mark the end of the Christian era, but the long period that elapsed between the original fall of Satan (see 9:1-2; 12:7-12) and his return only to be vanquished definitively by Jesus' death and resurrection (16:1-21). The passage has troubled interpreters from the beginnings of Christianity. To this day, many Christian traditions are determined by their interpretation of the nature and timing of the "thousand-year reign": amillenarian, premillenarian, postmillenarian, and dispensationalist. For a good survey explaining these terms, see Koester, Revelation, pp. 741-50.

39 Spectacularly and tragically evident in the contemporary unveiling of the widespread abuse of minors perpetrated by leaders within the Christian Churches, these are indeed "dark times" for many believing and practicing Christians. For an excellent recent focus upon the Catholic Church, see Keenan (2012). 
and the government kept the peace and demanded taxes." 40 This situation, however, could easily lead to an uncritical accommodation of the traditions and mores of the Greco-Roman world.

Such a way of life was unacceptable in the Christian church, the perfection of God's promises, founded upon the death and resurrection of Jesus. John writes to make them aware, to encourage them, and to instill hope in challenging times. He tells them that the faithfulness required of those who live in the blessedness of the post-Christ era had already been lived by people who were faithful unto death in the period between the original "fall" of Satan and humankind (see 9:1-2; 12:7-12) and the death and resurrection of Jesus (see 16:1-21; 20:1-6). The victory of the saints of Israel, already participating in the death and resurrection of Jesus, was the result of their obedience to the Law and their belief in the messianic promises of the prophets. They are already gathered in glory (see 6:9-11; 7:1-8; 14:1; 15:1; 20:1-6). John uses this message to address early Christians living the challenges of the in-between-time during which access to God is no longer through a temple in Jerusalem, but through the gift of the temple of the Lord God Almighty and the Lamb (21:22), the Christian community. For John, they have solid reasons for hope in dark times.

Conflicts of Interest: The author declares no conflict of interest.

\section{References}

Attridge, Harold W. 2002. Genre Bending in the Fourth Gospel. Journal of Biblical Literature 121: 1-21. [CrossRef] Aune, David E. 1997. Revelation. 3 vols. Word Biblical Commentary 52A-C. Dallas: Word.

Bauckham, Richard. 1993a. The Climax of Prophecy: Studies in the Book of Revelation. Edinburgh: T. \& T. Clark.

Bauckham, Richard. 1993b. The Theology of the Book of Revelation. New Testament Theology. Cambridge: Cambridge University Press.

Beale, Gregory K. 1999. The Book of Revelation. The New International Greek Testament Commentary. Grand Rapids: Eerdmans.

Boring, M. Eugene. 1989. Revelation, Interpretation. Louisville: John Knox Press.

Boxall, Ian. 2006. The Revelation of Saint John. Black's New Testament Commentaries. London: A and C. Black.

Boxall, Ian. 2013. Patmos in the Reception History of the Apocalypse. Oxford Theology and Religion Monographs. Oxford: Oxford University Press.

Brodd, Jeffrey, and Jonathan Reed, eds. 2011. Rome and Religion. A Cross-Disciplinary Dialogue on the Imperial Cult. Writings from the Greco-Roman World Supplement Series 5; Atlanta: Society of Biblical Literature.

Casey, Maurice. 1979. Son of Man. The Interpretation and Influence of Daniel 7. London: SPCK.

Charles, R. H. 1920. A Critical and Exegetical Commentary on the Revelation of St. John. International Critical Commentary. Edinburgh: T. \& T. Clark.

Collins, Adela Y. 1979. The Apocalypse. New Testament Message 22. Wilmington: Michael Glazier.

Collins, John J. 1993. Daniel, Hermeneia. Minneapolis: Fortress.

Collins, John J. 2015. Apocalypse, Prophecy, and Pseudeprigraphy. On Jewish Apocalyptic Literature. Grand Rapids: Eerdmans.

Corsini, Eugenio. 1980. Apocalisse prima e dopo. Turin: Società Editrice Internazionale.

Corsini, Eugenio. 1983. The Apocalypse. The Perennial Revelation of Jesus Christ. Translated and Edited by Francis J. Moloney. Good News Studies 5. Wilmington: Michael Glazier.

Corsini, Eugenio. 2002. Apocalisse di Gesù secondo Giovanni. Sestante. Turin: Società Editrice Internazionale.

Eire, Carlos M. N. 2016. Reformations. The Early Modern World, 1450-1650. New Haven: Yale University Press.

Foerster, Werner. 1968. Oros. In Theological Dictionary of the New Testament. Edited by Gerhard Kittel and Gerhard Friedrich. Translated by Geoffrey W. Bromiley. Grand Rapids: Eerdmans, vol. 5, pp. 475-87.

Friesen, Steven J. 2001. Imperial Cults and the Apocalypse of John. Reading Revelation in the Ruins. New York: Oxford University Press.

Giesen, Heinz. 1997. Die Offenbarung des Johannes. Regensburger Neues Testament. Regensburg: Pustet. 
Goldingay, John. 1989. Daniel. Word Biblical Commentary 30. Nashville: Thomas Nelson.

Howard-Brook, Wes, and Anthony Gwyther. 1999. Unveiling Empire. Reading Revelation Then and Now. Foreword by Elizabeth McAlister. Maryknoll: Orbis.

Keenan, Marie. 2012. Child Sexual Abuse and the Catholic Church: Gender, Power, and Organizational Culture. New York: Oxford University Press.

Klauck, Hans-Josef. 2003. The Religious Context of Early Christianity. A Guide to Greco-Roman Religions. Translated by Brian McNeil. Minneapolis: Fortress.

Koester, Craig S. 2014. Revelation. The Anchor Yale Bible 38A. New Haven: Yale University Press.

Lupieri, Edmondo F. 2009. A Commentary on the Apocalypse of John. Italian Texts and Studies on Religion and Society. Translated by Maria Poggi Johnson, and Adam Kamesar. Grand Rapids: Eerdmans.

MacMullen, Ramsey. 1984. Christianizing the Roman Empire (A.D. 100-400). New Haven: Yale University Press.

Moloney, Francis J. 2017. God, Eschatology, and 'This World': Ethics in the Gospel of John. In Johannine Ethics: The Moral World of the Gospel and Epistles of John. Edited by Sherri Brown and Christopher W. Skinner. Minneapolis: Fortress.

Moloney, Francis J. 2020a. The Apocalypse of John. An Alternative Commentary. Grand Rapids: Baker Academic.

Moloney, Francis J. 2020b. Reading Revelation at Easter Time. Collegeville: Liturgical Press.

Moyise, Steve. 1995. The Old Testament and the Book of Revelation. Supplements to the Journal for the Study of the New Testament 115. Sheffield: Sheffield Academic Press.

Paul, Pope, VI. 1974. The Divine Office. The Liturgy of the Hours According to the Roman Rite. London/Sydney/Dublin: Collins/E. J. Dwyer/Talbot.

Prigent, Pierre. 2001. Commentary on the Apocalypse of St. John. Translated by Wendy Pradels. Tübingen: Mohr Siebeck.

Resseguie, James L. 2009. The Revelation of John: A Narrative Commentary. Grand Rapids: Baker Academic.

Thompson, Leonard L. 1990. The Book of Revelation. Apocalypse and Empire. New York: Oxford University Press.

Vanni, Ugo. 1991. Liturgical Dialogue as a Literary Form in the Book of Revelation. New Testament Studies 37: 348-64. [CrossRef]

Translated and Edited by William C. Weinrich. 2011, Ancient Christian Texts. Latin Commentaries on Revelation. Downers Grove: IVP Academic.

(C) 2019 by the author. Licensee MDPI, Basel, Switzerland. This article is an open access article distributed under the terms and conditions of the Creative Commons Attribution (CC BY) license (http://creativecommons.org/licenses/by/4.0/). 